\title{
A POSSIBILIDADE DE APRESENTAÇÃO DE PROPOSTAS DE EMENDAS CONSTITUCIONAIS POR INICIATIVA POPULAR: A DEMOCRACIA, A CIDADANIA E A SOBERANIA POPULAR
}

\author{
THE POSSIBILITY OF PRESENTATION \\ OF PROPOSALS OF CONSTITUTIONAL \\ AMENDMENTS PER POPULAR INITIATIVE: \\ THE DEMOCRACY, THE CITIZENSHIP \\ AND THE POPULAR SOVEREIGNTY
}

\author{
Maxime Dal Molin Schneider ${ }^{1}$ \\ José Sérgio da Silva Cristóvam²
}

Resumo: O presente artigo tem como
área de exame o Direito Constitucio-
nal, sendo que sua linha de pesquisa
se dedica à discussão do instituto da
iniciativa popular constitucional. Sob

essa perspectiva, direciona-se ao posicionamento, predominantemente doutrinário, acerca da possibilidade do povo de flagrar o processo legislativo de reforma constitucional, apresentan-

1 Aluno concluinte da Escola Superior da Magistratura do Estado de Santa Catarina (Esmesc). Especialista em Direito Público pela Fundação Universidade Regional de Blumenau (FURB). Graduado em Direito pela Universidade do Sul de Santa Catarina (Unisul). Juiz Leigo no Juizado Especial Cível de Florianópolis-SC/Continente. Advogado. E-mail: max.dms@gmail.com

2 DoutoremDireitoAdministrativopelaUniversidadeFederaldeSanta Catarina(UFSC), com estágio em Doutoramento Sanduíche no Instituto Superior de Ciências Sociais e Políticas (ISCSP) na Universidade Técnica de Lisboa (Portugal). Mestre em Direito Constitucional pela UFSC. Especialista em Direito Administrativo pelo Complexo de Ensino Superior de Santa Catarina (Cesusc). Professor de Direito Administrativo nos Cursos de Graduação e Pós-Graduação em Direito Cesusc. Professor de Direito Administrativo na Esmesc, na ESA-OAB/SC e na ENA/Brasil, em convênio com a ÉcoleNationale d'Administration (I'ENA/França), bem como em cursos de pós-graduação em Direito. Membro fundador e presidente do Instituto Catarinense de Direito Público (ICDP). Membro fundador do Instituto de Direito Administrativo de Santa Catarina (IDASC) e da Academia Catarinense de Direito Eleitoral (ACADE). Membro efetivo do Instituto dos Advogados de Santa Catarina (IASC). Conselheiro Estadual da OAB/SC (triênio 2013-2015). Vice-Diretor Geral da ESA-OAB/SC (triênio 2013-2015). Presidente do Comitê de Mobilização para a Reforma Política (OAB/SC).Membro da Comissão de Direito Constitucional e da Comissão de Moralidade Pública da OAB/SC (triênio 2013-2015). Assessor Jurídico do Sindicato dos Trabalhadores na Rede Estadual de Ensino de Santa Catarina (SINTE/SC). Advogado militante na seara do Direito Público. E-mail: jscristovam@gmail.com 
do ao Congresso Nacional propostas de emendas à Constituição Federal. O ordenamento jurídico constitucional tem como prisma a observância dos princípios fundamentais da democracia (art. $1^{\circ}$, caput), da cidadania (art. $1^{\circ}$, inciso II) e da soberania popular (art. $1^{\circ}$, parágrafo único, e art. 14), os quais devem irradiar-se para todo o sistema jurídico. Partindo-se dessa ideia, analisaremos a iniciativa popular como mecanismo apto a sustentar a validade do exercício dos direitos políticos no âmbito do processo legislativo constitucional, já que, fazendo-se uma interpretação sistemática da Constituição, podemos afirmar se os cidadãos são a propor emendas à Constituição. Veremos também, que durante a Constituinte, houve uma supressão legislativa no processo de elaboração da $\mathrm{CRFB} / 88$, em que o instituto foi retirado do Projeto inicial e restou olvidado durante anos, mas que com o amadurecimento da sociedade deve novamente integrar o texto constitucional como forma de efetivação da democracia, da cidadania e da soberania da vontade popular.

Palavras-chave: Processo legislativo constitucional. Iniciativa popular. Emendas à constituição. Democracia. Cidadania. Soberania popular.

Abstract: This article it has the exam area do Constitutional Law, and his line of research is dedicated to the discussion of the institute of the cons- titutional popular initiative. From this perspective, aimed at positioning, mainly doctrinal, on the possibility of the people trigger the legislative process of constitutional reform, presenting to Congress proposed amendments to the Federal Constitution. The constitutional legal system has the prism observance of fundamental principles of democracy (art. 1, caput), citizenship (art. 1, item II) and popular sovereignty (art. 1, single paragraph, and art. 14), which should radiate to the entire legal system.Starting from this idea, we analyze the popular initiative as a mechanism able to sustain the validity of the exercise of political rights within the constitutional legislative process, since making a systematic and logical interpretation of the Constitution, we can say if citizens are legitimate to propose amendments to the Constitution.We will also see that during the Constituent Assembly, there was a legislative suppression in the process of drafting the CRFB/88, where the institute was removed from the initial design and remained forgotten for years, but with the maturing of society must again join the Constitution as a way to realization of democracy, citizenship and sovereignty of the popular will.

Keywords: Constitutional legislative process. Popular initiative. Amendments to Constitution. Democracy. Citizenship. Popular sovereignty.

\section{INTRODUÇÃ̃O}

A Constituição de 1988 é um marco para a história da democracia brasileira, trazendo direitos e garantias fundamentais 
aos cidadãos. Assim, o presente artigo pretende apresentar um panorama acerca dos princípios democráticos nela positivados, a partir do estudo da iniciativa popular constitucional sob a perspectiva da democracia, da cidadania e da soberania popular no Estado Democrático brasileiro.

A Constituição, fruto do Poder Constituinte originário, conferiu ao Congresso Nacional a competência para apreciar, discutir e votar as emendas constitucionais. Há, porém, uma norma constitucional fundamental segundo a qual todo poder emana do povo, que o exerce por meio de representantes eleitos ou diretamente nos termos do art. 14 da Constituição. Logo, o aludido dispositivo constitucional assegura a soberania popular, e, no seu inciso III, a possibilidade de iniciativa popular para propor a elaboração de leis, sem, contudo, referir-se expressamente às emendas constitucionais.

Em verdade, o exercício da cidadania não se limita aos períodos eleitorais, devendo os cidadãos participar ativamente nas decisões políticas do Estado, seja apresentando projetos de leis ou propostas tendentes à reforma constitucional, por meio das emendas.

Fica, de início, uma indagação: se o povo é o titular do Poder Constituinte originário, o qual é capaz de romper com ordem jurídica vigorante e dar ensejo a uma nova Constituição, então por que não poderia o próprio povo ter legitimidade para iniciar o processo legislativo constitucional da Constituição vigente?

Por essa razão, o estudo destina-se especificamente a discutir o instituto da iniciativa popular para emendar a Constituição e verificar se a vedação a esse instituto não teria o potencial de violar os princípios constitucionais fundamentais da democracia, da cidadania e da soberania da vontade popular.

Cumpre esclarecer, expressamente, que não há pretensão de esgotamento nesse estudo de temática revestida de tamanha 
complexidade e implicações jurídico-políticas, mas sim o fomento ao debate e a busca da concretização dos valores constitucionais a partir dessa nova proposta de canal de democracia participativa e cidadania ativa, pela via da proposta de emenda à Constituição por iniciativa popular.

\section{SOBRE A POSSIBILIDADE DE PROPOSTAS DE EMENDAS CONSTITUCIONAIS POR INICIATIVA POPULAR}

Uma das grandes novidades trazidas no bojo da nova ordem constitucional brasileira veio já estampada na sua dimensão constituinte, a partir do art. 24 do Regimento Interno da Assembléia Nacional Constituinte de 1987, que desde a sua instalação possibilitou aos cidadãos a apresentação de emendas populares ao Projeto de Constituição, sendo um marco democrático histórico de fundamental importância, uma vez que estreitou a relação povo-parlamento e legitimou os próprios trabalhos da nascente Assembléia Constituinte.

Para a época, após um penoso período de repressão causado pelo regime militar, esse direito foi um grande passo para o aprofundamento da democracia.

Inicialmente, para que uma emenda popular fosse admitida pela Comissão de Sistematização, deveria estar subscrita por mais de trinta mil eleitores, em listas organizadas por associações legalmente constituídas, as quais se responsabilizariam pela veracidade e regularidade das assinaturas.

Ao longo dos trabalhos da Constituinte, dezenas de emendas populares chegavam de todas as partes do país a Brasília, porém nem todas elas tiveram seu mérito analisado. No entanto, três emendas populares, dentre as que tiveram o mérito analisado pelos constituintes, tratavam especificamente sobre o tema da iniciativa popular constitucional $\left(\mathrm{n}^{\mathrm{o}} 21,22\right.$ e 56$)$. 
Essas emendas populares tinham um requisito em comum com o que temos hoje para a iniciativa popular de leis (art. 61, $\S 2^{\circ}$ ), ou seja, proposta subscrita por, no mínimo, $1 \%$ do eleitorado nacional. Como justificativa, ressaltavam que o poder emana do povo, conforme afirma o princípio universal da democracia, devendo este poder ser exercido pelo povo por meio de uma garantia efetiva de participação popular nas decisões do Estado e na elaboração de leis, para assim, darmos legitimação ao poder constituído.

Como pudemos verificar, as emendas populares que pleiteavam a introdução de um dispositivo constitucional que permitisse a iniciativa popular para proposição de emendas à Constituição foram apresentadas. Contudo, apesar de terem sido rejeitadas ou consideradas prejudicadas pelo relator, sob a alegação de que as propostas já constavam do Projeto de Constituição em apreciação, esse fato não retira a importância do movimento, pois as emendas populares serviram à fusão dos textos na hora de se votar o Projeto Final, que acabou por excluir esse importante instrumento democrático.

Sabe-se que alguns constituintes mantiveram em primeiro lugar o seu compromisso com o interesse da sociedade e o fomento aos mecanismos de democracia direta, contudo, outros mais conservadores tiveram receio de abraçar às propostas de emendas populares que buscavam a inclusão deste extraordinário instrumento democrático.

Acreditamos que, ante milhões de assinaturas que o movimento das emendas populares conquistou, esses parlamentares tiveram temor que o povo poderia alcançar facilmente o percentual exigido para proposição de emendas, o que poderia ameaçar, segundo alguns, a legitimidade do próprio sistema representativo, do qual não abriam mão.

Em verdade, este movimento tinha o objetivo precípuo de 
fortalecer as instituições, ajudando o próprio Congresso Nacional a readquirir suas prerrogativas. $O$ povo não quer se intrometer em assuntos pertencentes aos legisladores, mas sim ser fonte de alimentação destes (MICHELES, 1989, p. 242).

Sem dúvida, caso essas emendas tivessem efetivamente atingido sucesso, hoje teríamos um canal de diálogo mais aberto entre o Congresso e os diversos segmentos da população, onde os parlamentares poderiam ouvir às reivindicações da sociedade em geral, e não somente daqueles grupos socioeconômicos fortes que não raro são os maiores financiadores de campanhas eleitorais.

Pois bem, como em diversos temas relacionados ao Direito sempre existem duas correntes, em relação à PEC por iniciativa popular não é diferente. A Constituição explicita no seu art. 60, incisos I, II, e III, o rol de legitimados para proposição de emendas constitucionais, em que facilmente podemos notar que não há a previsão da iniciativa popular, já que, o que hoje seria o inciso IV foi excluído na votação do Projeto Final em Plenário.

Por isso, a primeira corrente basicamente entende que a iniciativa popular não se encontra expressamente positivada no rol de legitimados do art. 60, o qual seria taxativo, motivo pelo qual seria inadmissível. ${ }^{3}$

Por sua vez, há uma corrente que verificamos sustentar o entendimento mais acertado, quando defende que o art. 14, inciso III, não faz qualquer tipo de restrição à determinada espécie normativa, e em sua análise conjuntamente com o pa-

3 Entre os defensores dessa corrente, podemos citar: BENEVIDES, Maria Victória de Mesquita. A cidadania ativa: referendo, plebiscito e iniciativa popular. 3. ed. São Paulo: Ática, 1998, p. 130; CARVALHO, Kildare Gonçalves. Técnica legislativa. 4. ed., rev. atual. eampl. Belo Horizonte: Del Rey, 2007, p. 164; DANTAS, Paulo Roberto de Figueiredo. Curso de direito constitucional. 2. ed. São Paulo: Atlas, 2013, p. 75; MELO, Mônica de. Plebiscito, referendo e iniciativa popular: mecanismos constitucionais de participação popular. Porto Alegre: Sérgio A. Fabris, 2001, p. 194; PAULO, Vicente; ALEXANDRINO, Marcelo. Processo legislativo. Niterói: Impetus, 2005, p. 207. 
rágrafo único do art. $1^{\circ}$, seria possível a defesa aqui alinhada, inclusive em homenagem à própria soberania popular. ${ }^{4}$

Nesse sentido, iremos aprofundar somente essa segunda corrente, pois é a linha de pensamento compartilhada entre os autores deste artigo.

Iniciando pelos magistérios do constitucionalista Pedro Lenza, a primeira parte do parágrafo único do art. $1^{\circ}$, assegura, in verbis, que "Todo o poder emana do povo", e mais adiante, o inciso III do art. 14, estabelece uma das formas em que a soberania popular é exercida pelo próprio povo, ou seja, pela iniciativa popular. Por essas razões, o referido autor defende sua posição a partir de uma interpretação sistemática da Constituição (LENZA, 2014, p. 633).

O constitucionalista José Afonso da Silva também aceita uma interpretação sistemática do art. $60 \mathrm{c} / \mathrm{c}$ os arts. $1^{\circ}$, parágrafo único, e 14, inciso III, para admitirmos a iniciativa popular constitucional com os mesmos requisitos da iniciativa popular legislativa (SILVA, 2016, p. 65-66).

Apoiado nessa abordagem teórica, Renato Siqueira de Pretto propõe uma alteração constitucional no rol de legitimados à proposição de emendas, sob pena de tornarmos mais tímida a já sofrida organização política de nossa sociedade (MORAES; KIM, 2013, p. 125).

Por seu turno, o constitucionalista Paulo Bonavides deduz que a iniciativa popular constitucional é tão possível quanto a iniciativa popular legislativa, não havendo distinção entre ambas, reconhecendo, até mesmo, que o povo seja o revisor das emendas constitucionais (BONAVIDES, 2008, p. 204).

4 Essa corrente, que é sustentada por grande parte da doutrina, tem como destaques: BONAVIDES, Paulo. Curso de direito constitucional. 22. ed. atual. São Paulo: Malheiros, 2008, p. 204-207; LENZA, Pedro. Direito constitucional esquematizado. 18. ed. rev., atual. eampl. São Paulo: Saraiva, 2014, p. 633; SILVA, José Afonso. Curso de direito constitucional positivo. 33. ed. São Paulo: Malheiros, 2016, p. 65-66. 
Além disso, dialogando com todas essas posições favoráveis ao instituto em questão, encontra-se constitucionalmente consagrado o princípio fundamental de legitimidade política no art. $1^{\circ}$, parágrafo único, o qual já foi exaustivamente repetido, restando claro que o povo se manifesta através de seus representantes ou o faz diretamentepelas formas previamente estabelecidas no art. 14.

Nesse contexto constitucional, o art. 14 previu quatro formas de manifestação da soberania popular: o sufrágio eleitoral, o plebiscito, o referendo e, por último, a iniciativa popular legislativa.

Sob essa perspectiva vale reproduzir as lições de Silva, que sustenta que a democracia repousa sobre dois princípios fundamentais: a) o da soberania popular, de onde podemos exprimir que o povo é a única fonte de poder, e de onde emana todo esse poder; b) a participação, direta ou indireta, do povo no poder, para efetivarmos a expressão vontade popular com ou sem representação (SILVA, 2016, p. 133).

Sendo assim, o regime democrático "é aquele em que as decisões políticas são tomadas em estreita vinculação com a vontade popular. Trata-se, em síntese, do governo do povo, pelo povo e para o povo". (DANTAS, 2013, p. 137).

Logicamente, se o povo é quem detém a legitimidade de convocar uma Assembleia Constituinte para romper com a ordem jurídica vigente e, consequentemente, dar início a uma nova Constituição, que é a lei fundamental do nosso Estado e na qualas demais normas jurídicas devem encontrar seu fundamento último, por que não poderia ele mesmo ter o direito de apresentar propostas de mudanças no texto constitucional?

Bonavides possui a resposta mais acertada, senão vejamos:

O sistema de Convenção nasceu do chamado "princípio do paralelismo das formas", por onde resulta que um ato jurí- 
dico só se modifica mediante o emprego de formas idênticas àquelas adotadas para elaborá-lo. $\mathrm{Ou}$, em algumas palavras, aplicado o conceito à reforma constitucional: o órgão que fez a Constituição é o único apto a alterá-la (BONAVIDES, 2008, p. 206).

Com efeito, a resposta para a assertiva igualmente encontra fundamento no art. 60, uma vez que o Poder Constituinte originário, ao promulgar a Constituição, consagrou o rol de legitimados a propor as emendas constitucionais, mas não contemplou a iniciativa popular no seu texto, apesar daquelas emendas populares $(21,22$ e 56) terem apresentadopropostas para a inclusão da iniciativa popular no rol de legitimados do referido artigo, conforme já visto.

Ao nosso juízo, talvez essa tenha sido um grande pecado democrático da $\mathrm{ANC}$, que até a votação em Plenário admitia, expressa e especificamente, a iniciativa popular em matéria de emenda constitucional. No Plenário, entretanto, alas conservadoras derrubaram essa possibilidade clara que constava do Projeto aprovado na Comissão de Sistematização (art. 74, IV) em dezembro de 1987, pelo que, em março de 1988, o referido inciso foi excluído na votação em Plenário. ${ }^{5}$

O tema não teve maiores repercussões na sociedade ou até mesmo na mídia, uma vez que as atenções estavam voltadas exclusivamente para o debate que estabelecia o presidencialismo como sistema de governo.

Vale à pena destacar o esforço da constituinte Myryan Portella para reintroduzir no texto da emenda substitutiva o direito do povo de participar do processo legislativo, uma vez que já havia sido aprovado o princípio da soberania popular, o qual, por si só, já confere ao povo o direito de participar diretamente no processo legislativo e político. Lembrou, ainda, que as

5 Anais da Constituinte.Disponível em: $<$ http://www.senado.gov.br/>. Acesso em: 3 jun. 2016. 
democracias ocidentais consagram instrumentos de participação popular, principalmente nos países do continente Europeu, onde têm vivenciado resultados positivos. Por fim, defendeu a adoção de uma terceira via, ou seja, um sistema alternativo que possibilite a participação direita do povo ao lado do sistema tradicional de representação política. ${ }^{6}$

A aprovação da emenda permitindo a iniciativa popular para elaboração de leis foi considerada uma conquista tão grande, que o povo, sabendo que não se pode ter tudo, contentou-se com o direito alcançado, conquanto devesse ter manifestado o seu descontentamento com a atitude dos constituintes contrários à medida de democratização do sistema político-"participativo".

\subsection{A constitucionalidade da iniciativa popular constitucional}

A constitucionalidade da proposta de emenda que pretende introduzir a iniciativa popular constitucional deve ser analisada sob dois aspectos: primeiro, se a proposição não fere o núcleo dos limites expressos constante do art. 60, inciso IV; segundo, se não estaria ferindo, eventualmente, limites implícitos.

Alguns autores advogam que a alteração do procedimento de reforma não promoveria qualquer ofensa à Constituição, outros consideram uma afronta, sob o argumento de que o procedimento de reforma à Constituição, como limite implícito, seria intocável.

Silva interpreta que, não só é constitucional, como não está excluída a aplicação dos institutos de participação popular em matéria constitucional, pois está expressamente previsto que o poder que decorre do povo será exercido por meio de representantes ou diretamente nos termos da Constituição (art. $1^{\circ}$, parágrafo único), bem como que a soberania popular 
será exercida por iniciativa popular (art. 14, inciso III) (SILVA, 2016, p. 65-66).

De fato, a tese do renomado constitucionalista é de que, com base na interpretação sistemática da Constituição, não haveria óbices à apresentação de emenda constitucional por iniciativa popular, bastando que a proposta de emenda respeitasse as regras previstas para iniciativa popular de leis $\left(\operatorname{art} .61, \S 2^{\circ}\right)$.

Maurício Antonio Ribeiro Lopes considera a tese de Silva bastante pertinente, e faz apenas uma ressalva no tocante à necessidade de se resguardar a rigidez constitucional, pois é imprescindível que exista um processo especial, mais dificultoso, para sua modificação, do que o de simples leis (LOPES, 1993, p. 201).

Ademais, corroborando o ponto de vista de Lopes, José Duarte Neto reconhece que é possível a inclusão da iniciativa popular para a reforma da Constituição, desde que não seja minorado o núcleo essencial da Constituição, pois dessa forma estaria preservada a rigidez constitucional. Nesse sentido, manifesta-se:

Com a pretendida inclusão dos cidadãos, ao lado dos demais legitimados, como agentes deflagradores do processo de reforma constitucional, fatalmente estaria sendo alterado o princípio da democracia participativa idealizado pelo constituinte. Essa alteração, contudo, não viria como uma transmutação pura e simples da ideia originária, mas sim como um aprimoramento (DUARTE NETO, 2005, p. 124).

O julgamento de Duarte Neto é conexo com a nossa concepção de que estaremos aperfeiçoando o sistema da democracia participativa e não desmerecendo a democracia representativa que é indispensável no nosso país em virtude de suas dimensões continentais.

Aliás, ao admitirmos a iniciativa popular de emendas à Constituição, não estaremos minorando o núcleo essencial da 
Constituição, e sim aprimorando, já que não podemos colocar o mecanismo da democracia direta em posição hierarquicamente inferior à representação popular, pois os representantes do povo são meros mandatários do poder.

Em suma, é possível concluir que, sendo o Brasil um Estado Democrático de Direito e a cidadania um de seus fundamentos (art. $1^{\circ}$, inciso II), o mecanismo da iniciativa popular para dar início ao processo de reforma constitucional, não só é constitucional, como é um meio de efetivação da participação popular na vida política do país, como concretização da democracia, bem como de garantia da soberania da vontade popular como um direito fundamental de todos e que deve ser respeitado pelos Parlamentares, de modo a manter o compromisso com o interesse da sociedade, convertendo-se, eventualmente, PEC's por iniciativa popular em normas constitucionais que exprimam as aspirações populares.

\subsection{A iniciativa popular nas emendas às constituições estaduais e no direito comparado}

A Constituição Federal possibilitou, no seu art. 25, que os Estados-membros elaborassem suas próprias Constituições, observando os princípios e as competências que não lhes sejam vedadas pela Constituição Federal.

Em vista disso, as Constituições estaduais atendendo ao princípio da simetria praticamente acabaram por reproduzir a Constituição Federal, mas a maioria delas trouxeem seus textos a iniciativa popular para proposição de emendas à Constituição estadual.

Dessa forma, dezesseis das vinte e seis Constituições estaduais (mais a do DF) incluíram em seus textos a possibilidade de a população deflagrar diretamente o processo de emenda à Constituição estadual, inclusive a Constituição do Estado de 
Santa Catarina, em seu art. 49, IV, explicitamente conferiu esse direito aos cidadãos catarinenses.

Não obstante, apesar desses estados terem introduzido a iniciativa popular constitucional para receberem propostas de emendas ao próprio texto, trata-se de um direito que não é muito exercido pela população, uma vez que é um processo penoso, ante a dificuldade de se conseguir o número necessário de subscrições para iniciativa do processo legislativo estadual.

O fato é que a população e os setores organizados da sociedade parecem preferir encaminhar sugestões aos Parlamentares estaduais para que encampem suas ideias, a fim de que a dificuldade de subscrições não se torne empecilho à prática e à concretude desse direito.

Por outro lado, pelo princípio da simetria das formas, Gilmar Mendesdefende que qualquer forma de "conflito entre a norma do poder constituinte do Estado-membro com alguma regra editada pelo poder constituinte originário resolve-se pela prevalência desta, em função da inconstitucionalidade daquela”. (MENDES, 2013, p. 793).

Portanto, ao que parece, o referido autor entende que as Constituições estaduais que preveem expressamente a possibilidade da iniciativa popular como mecanismo de início ao processo de emenda às respectivas Constituições estariam inquinadas de vícios de inconstitucionalidade, por não respeitarem o processo legislativo da Constituição Federal, o qual não prevê expressamente essa possibilidade, um entendimento que merece reservas e ressalvas, não somente pelo que já fora até aqui defendido, mas também pelas possibilidades decorrentes da interpretação sistemática da Constituição estadual e sua relação com a ordem constitucional federal.

Com relação à iniciativa popular em outros países, faremos uma abordagem geral, já que o nosso objetivo principal 
é analisar o instituto na ordem constitucional brasileira. Por isso, apenas a título elucidativo, faz-se necessário analisarmos esse mecanismo democrático em alguns outros países, onde o instrumento de participação popular tem alcançado resultados positivos para o desenvolvimento democrático.

Na Suíça, o povo se reúne em assembleias para deliberar sobre vários assuntos, podendo, inclusive, propor a revisão da Constituição por iniciativa popular, que depois será submetida a uma aprovação pela maioria dos cidadãos em referendo obrigatório.

$\mathrm{Na}$ Constituição italiana, as emendas que promovam inovações no texto fundamental devem ser submetidas a referendo popular quando, três meses após a sua publicação, quinhentos mil eleitores o solicitarem; a Constituição francesa também as submete a referendo.

Constatamos, assim, que a exemplo desses três países do velho continente, existe um admirável meio de controle social sobre as inovações constitucionais.

Nos Estados Unidos, país com forte tradição democrática, não há previsão da iniciativa popular constitucional, contudo, o mecanismo está previsto em dezessete dos cinquenta estados, à semelhança do que ocorre no sistema brasileiro.

No que concerne aos países sul-americanos que preveem expressamente a iniciativa popular constitucional em suas Constituições, podemos citar o Uruguai, o Peru, a Colômbia e a Venezuela.

$\mathrm{O}$ art. 331 da Constitución uruguaya faculta a reforma constitucional por iniciativa de $10 \%$ dos cidadãos inscritos no Registro Civil Nacional, os quais deverão apresentar um projeto ao Presidente da Assembleia Geral que submeterá a decisão popular imediata; já o art. 206 da Constitución peruana, estabelece que toda reforma constitucional, depois de aprovada por maioria 
absoluta no Congresso, deve ser ratificada mediante referendo; o art. 155 da Constitución colombiana permite a apresentação de propostas de reforma constitucional, desde que subscritas por 5\% do censo eleitoral; por fim, o art. 342 da Constitución venezuelana, em consonância com a regra anteriormente citada, admite a reforma constitucional, desde que solicitada por $15 \%$ dos eleitores inscritos no Registro Civil e Eleitoral.

Em virtude desse comparativo, facilmente podemos perceber que a sociedade tem um papel de protagonista, onde pelo menos sob o prisma normativo a participação popular, visando os interesses da coletividade, ganha destaque nos países vizinhos.

Portanto, concluímos alertando para a necessidade de superarmos essa contraposição que a democracia participativa acarreta nos políticos brasileiros, pois isso acaba por deslegitimar e enfraquecer o sistema representativo o invés de aproximar o Legislativo da população para ouvir às vontades da sociedade.

\section{PROPOSTAS QUE TRAMITAM NO CONGRESSO NACIONAL PARA INCLUIR A EMENDA CONSTITUCIONAL POR INICIATIVA POPULAR}

Parece-nos que o desenvolvimento da política brasileira e o amadurecimento político da sociedade tendem a indicar a necessidade de expressa regulamentação de um instrumento legislativo que assegure ao povo apresentar propostas de emendas à Constituição.

Nesse sentido, existem duas propostas que caminham concomitantes:

a) PEC no 394/2001, de iniciativa da Câmara dos Deputados, que propõe alterar a redação dos arts. 60 e 103 da Constituição Federal, para permitir a iniciativa popular na propositura de emenda à Constituição e na ação direta de inconstituciona- 
lidade. Em sua fundamentação o autor salienta a importância da proposta para o processo de consolidação da democracia brasileira, dando concretude ao princípio da soberania popular inscrito no art. $1^{\mathrm{o7}}$;

b) PEC n 03/2011, de iniciativa do Senado Federal, acrescenta o inciso IV ao caput do art. 60 e o $\S 3^{\circ}$ ao art. 61 da Constituição Federal, e altera a redação do $\S 2^{\circ}$ também do art. 61, para viabilizar a apresentação de propostas de emenda à Constituição de iniciativa popular e facilitar a apresentação e a apreciação de projetos de lei respectivos.

A explicação da emenda é a de possibilitar a PEC por iniciativa popular, para estabelecer que esse mecanismo democrático e de participação dos cidadãos poderá ser exercido pela apresentação, à Câmara dos Deputados, de PEC com apoio de eleitores correspondentes a, pelo menos, $0,5 \%$ dos votos dados na última eleição geral para a Câmara dos Deputados, não computados os votos em branco e nulos, distribuídos por $1 / 3$, ou mais, das unidades da Federação, com um mínimo de $1 / 10 \%$ do eleitorado que haja votado em cada um deles; e acrescenta que os projetos de iniciativa popular tramitarão em regime de urgência, salvo decisão em contrário do Plenário da Casa Legislativa. ${ }^{8}$

Em que pese existirem PEC's objetivando a inclusão da iniciativa popular no rol dos legitimados do art. 60, Jerson Carneiro Gonçalves Junior, utilizando-se do princípio da unidade da Constituição, defende que esse direito já existe ante a interpretação sistêmica que se deve dar à Constituição (já defendido por alguns autores anteriormente), não havendo a

\footnotetext{
7 A PEC após diversos arquivamentos pelo término da legislatura encontra-se parada na Câmara dos Deputados.

8 A PEC teve parecer favorável do Relator, Senador Lindbergh Farias, na CCJC, e o texto foi aprovado pelo Plenário do Senado em 2013 e, posteriormente, remetida à Câmara dos Deputados, em 2013, sob o n 286/2013, onde se encontra na CCJC da Câmara, aguardando o parecer do Relator, Deputado Rodrigo Pacheco, para apreciação da proposta (caso aprovada em Plenário, o inciso IV passará a integrar o rol de legitimados do art. 60 da Constituição Federal).
} 
necessidade de se emendar a Constituição para suprir referida lacuna legislativa (GONÇALVES JUNIOR, 2012, p. 252).

A cidadania, como umdos fundamentos da nossa República (art. $1^{\circ}$, inciso II), instrumentaliza-se como participação política e social do cidadão nas atividades do Estado, e como alicerce da democracia ela se fortalece na medida em que se provoca maior participação política e no processo legislativo.

Nesse caminho, de uma vez por todas, devemos expressamente garantir ao povo a iniciativa de projeto de emenda constitucional, pois, de fato, ainda existe um grande descompasso entre a realidade social e a Constituição. A sociedade, a política e o Direito evoluíram, e com o amadurecimento da sociedade desde a democratização do país, imprescindível se faz a aprovação da PEC $n^{\circ} 03 / 2011$, de iniciativa do Senado (PEC n ${ }^{\circ}$ 286/2013 na Câmara), possibilitando uma maior sintonia da nossa ordem constitucional com as tendências do constitucionalismo contemporâneo.

\section{CONCLUSÃO}

A questão da liberdade política popular como maneira de se concretizar a participação dos cidadãos na formação de normas constitucionais, tem cada vez mais sido levantada e tem se destacado com frequência nos debates sobre o Direito Constitucional e o Processo Legislativo.

Essa reflexão foi colocada a serviço do reconhecimento e da importância da iniciativa popular constitucional como meio apto à garantia da soberania popular, cujo assunto não deve se encerrar ao debate meramente acadêmico; pelo contrário, até que consigamos conquistar ou pelo menos nos aproximar mais do ideal democrático proposto pela Constituição, o povo deve continuar lutando pela ampliação do espaço de diálogo junto aos governantes, externando seus pensamentos e suas sugestões. 
Por isso, a fim de que o tema incitasse maiores discussões acadêmicas, buscamos apresentar alguns aspectos destacados relativos à iniciativa popular constitucional como mecanismo de efetivação da democracia direta e participativa, da cidadania ativa e da soberania da vontade popular, princípios constitucionais fundamentais que norteiam todo o processo legislativo constitucional e que conferem legitimidade ao regime adotado pelo Estado democrático de direito.

Os princípios em destaque revelam a verdadeira razão de ser e a essência do Estado brasileiro, de forma a garantir a unidade e manutenção de um modelo de Estado democrático cujas demais normas devem ser interpretadas observando tais mandados constitucionais, sob pena de ferir o sistema democrático e a legitimidade dos representes.

Sendo assim, o Estado democrático de direito garante a legítima democracia com a participação direita do povo nos destinos da sociedade, sendo importante essa valorização institucional das propostas de iniciativa popular que visem preservar a autonomia dos cidadãos frente às propostas dos partidos políticos, que às vezes tomam de assalto e até mesmo escamoteiam algumas concepções de interesse público em uma aliança espúria com grandes grupos econômicos e financiadores de campanha.

Seguindo a linha adotada pela corrente doutrinária aqui apresentada e defendida, entendemos que uma interpretação sistemática da Constituição não leva a outra direção que não a de admitir o instituto da emenda constitucional por iniciativa dos cidadãos.

Nessa dinâmica, torna-se imprescindível a superação da interpretação literal dos dispositivos constitucionais expressos, para que façamos uma interpretação voltada ao fortalecimento dos valores e princípios constitucionais propostos pelo constituinte originário, em especial, a democracia, a cidadania e a 
soberania popular para entendermos o sistema como um todo.

A Constituição de 1988 é o fruto de um processo tenso, criativo, polêmico e instável, sendo que o texto constitucional herdou virtudes e defeitos, contradições e avanços. Inaugurou o seu texto a batizar a República Federativa do Brasil como um Estado democrático de direito, que tem na democracia um dos seus pilares e, logo adiante, assegurou a cidadania e a soberania popular como fundamentos dessa República Federativa e premissas básicas atinentes à legitimidade política do sistema democrático representativo.

Quando do processo constituinte o Projeto de Constituição previa, dentro do rol de legitimados, a iniciativa popular como meio apto a deflagrar o processo de reforma constitucional, contudo, durante as votações em Plenário o mecanismo foi suprimido pelos constituintes mais conservadores, uma vez que entendiam que ele retirava a legitimidade do sistema representativo e das decisões do Parlamento, ameaçando seus próprios ideais e interesses partidários, comumente colocados à frente dos interesses sociais na política brasileira.

Entretanto, não se pode permitir essa distorção da democracia representativa, emprestando uma falsa aparência de "poder popular", enquanto esse sistema não permite, na verdade, que os cidadãos exerçam o poder, diante da indisposição da maioria dos Parlamentares em levar adiante a implementação de mais mecanismos de democracia direta, como no caso da iniciativa popular constitucional.

A Constituição consagrou a democracia após um longo e árduo período de ditadura militar, onde foram suprimidos direitos e garantias fundamentais dos cidadãos. Portanto, não se pode admitir essa nova ordem constitucional com uma fachada democrática apenas para dar legitimidade ao regime, quando, na realidade, a vocação democrática por vezes é muito mais (ou 
quase completamente) formal do que substancial, a manter os cidadãos reféns de discursos enganadores dos seus representantes, a governar voltados aos interesses de uma pequena parcela da população, violando o próprio espírito do Estado democrático e social de direito.

Sabemos que a democracia representativa é incompleta e longe do que o constituinte prometera, mas é por meio da ampliação da participação social e do controle organizado dos cidadãos, que poderá ser aprofundada a democracia e a cidadania.

$\mathrm{Na}$ conjuntura atual, não admitirmos que o povo inicie o processo legislativo de reforma da Constituição, através das PEC's, significa amesquinhar a ordem constitucional a partir de uma frágil concepção de democracia direta, com o reforço a um decadente e desacreditado sistema representativo, que visa muito mais interesses de grupos político-partidários ou de setores econômicos específicos do que o efetivo interesse da sociedade.

Sabe-se que o Brasil é relativamente novo no que diz respeito à democracia, pois há menos de trinta anos que saímos de um duro regime militar. Já foi um grande avanço a conquista do tão sonhado regime democrático (pelo menos em termos de previsão constitucional), mas ainda estamos longe do ideal democrático experimentado por outros países.

A Constituição da República não acompanhou a evolução da sociedade nesse aspecto de democracia participativa, uma vez que o sistema representativo tem resistido à interferência popular nas decisões políticas e administrativas, ainda que seja efetivamente o povo o legítimo titular do poder, conforme assegura o parágrafo único do art. $1^{\circ}$.

Inegavelmente, ainda que tenhamos experimentado um considerável amadurecimento social, político e jurídico na sociedade brasileira, não conseguimos evitar um hiato constitucional, de 
forma que temos um verdadeiro descompasso entre a realidade social e a Constituição, por vezes fora de sintonia com algumas tendências do constitucionalismo contemporâneo.

Com efeito, a maneira de corrigirmos essa lacuna para aproximarmos a Constituição da realidade vivida pela sociedade e do ideal de democracia almejado, pode passar pela aprovação, pela Câmara dos Deputados, da PEC 286/2013 (PEC no 03/2011, de iniciativa do Senado, onde já foi aprovada), com a inserção definitiva da iniciativa popular no rol de legitimados do art. 60 da Constituição Federal.

Por certo, eventuais entraves da democracia brasileira não devem retirar do povo a esperança no aprimoramento das instituições democráticas, nunca se olvidando da difícil tarefa que teve para conquistá-la. Uma caminhada repleta de obstáculos, mas que certamente reserva a ampliação das conquistas relacionadas àquele ideal democrático prometido e merecido.

\section{REFERÊNCIAS}

BENEVIDES, Maria Victória de Mesquita. A cidadania ativa:referendo, plebiscito e iniciativa popular. 3. ed. São Paulo: Ática, 1998.

BONAVIDAES, Paulo. Curso de direito constitucional. 22. ed. São Paulo: Malheiros, 2008.

BRASIL. Câmara dos Deputados. Disponível em: <http://www2.camara.leg.br>. Acesso em: 3 jun. 2016.

. Constituição (1988). Constituição da República Federativa do Brasil. Disponível em:<http://www.planalto.gov.br/ccivil_03/constituicao/constituicaocompilado. htm>. Acesso em: 3 jun. 2016.

Senado Federal. Disponível em: <http://www12.senado.leg.br/hpsenado>. Acesso em: 3 jun. 2016.

CARVALHO, Kildare Gonçalves. Técnica legislativa. 4. ed. rev. atual. eampl. Belo Horizonte: Del Rey, 2007.

COLÔMBIA (1991). Constitución. Constitución Politica de la República de Colombia de 1991. Disponível em: <http://www.procuraduria.gov.co/guiamp/media/file/Macroproceso\%20Disciplinario/Constitucion_Politica_de_Colombia.htm $>$. Acesso em: 3 jun. 2016. 
DANTAS, Paulo Roberto de Figueiredo. Curso de direito constitucional. 2. ed. São Paulo: Atlas, 2013.

DUARTE NETO, José. A iniciativa popular na Constituição Federal. São Paulo: Revista dos Tribunais, 2005.

GONÇALVES JUNIOR, Jerson Carneiro. O cidadão legislador: iniciativa popular de emenda constitucional no estado democrático de direito. São Paulo, 2012.

LENZA, Pedro. Direito constitucional esquematizado. 18. ed., rev., atual. e ampl. São Paulo: Saraiva, 2014.

LOPES, Maurício Antonio Ribeiro. Poder constituinte reformador: limites e possibilidades da revisão constitucional brasileira. São Paulo: Revista dos Tribunais, 1993.

MELO, Mônica de. Plebiscito, referendo e iniciativa popular: mecanismos constitucionais de participação popular. Porto Alegre: Sérgio A. Fabris, 2001.

MENDES, Gilmar Ferreira; BRANCO, Paulo Gustavo Gonet. Curso de direito constitucional. 8. ed., rev. e atual. São Paulo: Saraiva, 2013.

MICHELES, Carlos et al. Cidadão constituinte: a saga das emendas populares. Rio de Janeiro: Paz e Terra, 1989.

MORAES, Alexandre de; KIM, Richard Pae. Cidadania: o novo conceito jurídico e a sua relação com os direitos fundamentais individuais e coletivos. São Paulo: Atlas, 2013.

PAULO, Vicente; ALEXANDRINO, Marcelo. Processo legislativo. Niterói: Impetus, 2005.

PERU. Constitución (1993). Constitución Politica del Perú de 1993.Disponível em: $<\mathrm{http}$ //www.congreso.gob.pe/Docs/files/constitucionpolitica-27-04-2015.pdf $>$. Acesso em: 3 jun. 2016.

SANTA CATARINA. Constituição (1989). Constituição do Estado de Santa Catarina de 1989. Disponível em: <http://www.alesc.sc.gov.br >. Acesso em: 3 jun. 2016.

SILVA, José Afonso da.Curso de direito constitucional positivo. 39. ed., rev. e atual. São Paulo: Malheiros, 2016.

URUGUAI. Constitución (1967). Constitución de la República Oriental del Uruguay de 1967. Disponível em: <http://www.parlamento.gub.uy/constituciones/const967. htm>. Acesso em: 3 jun. 2016.

VENEZUELA (2000). Constitución de la República Bolivariana de Venezuela de 2000. Disponível em: <http://www.cne.gob.ve/web/normativa_electoral/constitucion/ indice.php>. Acesso em: 3 jun. 2016.

Artigo recebido em 10/06/2016

Artigo aprovado em 10/08/2016 